\title{
Clinical and epidemiological patterns of ano-genital warts among male patients in Erbil city, Iraq
}

Khalis B. M. Ali, Abdul-jabbar M. A. Al-Soudani, Sherzad A. Ismail Consultant Dermatologist, College of Medicine, Hawler Medical University, Erbil.

(Ann. Coll. Med. Mosul 2012; 38 (2): 28-34).

Received: $12^{\text {th }}$ Sep. 2011; Accepted: 15 ${ }^{\text {th }}$ Jul. 2012.

\section{ABSTRACT}

Background and objectives: Ano-genital warts consist of epidermal and dermal papules or nodules on the perineum, genitalia, crural folds, and anus. Up to the researchers' knowledge, no study concerning the genital warts in Erbil city was published, which was a motivation to study this problem, regarding the epidemiological and clinical patterns of this disease in Erbil city.

Patients and methods: This is a cross-sectional study; the data collected conveniently from male patients that have clinical features of genital warts attending two private dermatology clinics in Erbil city from $15^{\text {th }}$ June 2009 through $15^{\text {th }}$ June 2011.

Results: In this study, 45 male adults were included; their ages ranged from 20 to 49 years, with mean \pm SD of $29.8 \pm 6.017$. The highest rate of genital wart was among age group of $25-29$ years $(35.6 \%)$. Other statistics are; $(71.1 \%)$ of study sample were married; $(40 \%)$ were alcoholics; $(88.9 \%)$ were not using condom in their sexual contact, $(66.7 \%)$ had more than one sexual partner, $(53.3 \%)$ of the cases were illiterate or have primary school education and no one of the cases was homosexual. Sixty percent of the lesions were papular in shape, $(53.3 \%)$ were affecting more than one site of external genitalia, (91\%) of the patients had multiple warts, $(11.1 \%)$ had past history of one of STIs (sexually transmitted infection), $(15.6 \%)$ of the cases were associated with other sexually transmitted infections and all the cases were contracted through sexual contact.

Conclusion: The study concluded that the genital warts are low or infrequent in Erbil city when compared to other areas. The existence of traditional inhibition imposed by the religion and the society on the sexual behavior may be a factor in the low rate of the disease in this community.

Keywords: Clinical, epidemiological, ano-genital warts.

الأهداف: الفالول الجنسي يتكون من حبوب من بشرة أو أدمة الجلد ينتشر في المناطق التناسلية للإنسان. حسب معرفة الباحثين لا يوجد بحث منشور حول هذا المرض في مدينة أربيل، مما شجعهم لأجر اء هذا البحث لتسليط الضوء البن على هذا المرض من خلال هذا البحث. المرضى والطرق: تم جمع المعلومات من عينة مقطعية من المرضى المصابين بالفالول ألجنسي المر اجعين للعيادة الخاصة لإثنين من أطباء الجلدية في مدينة أربيل.

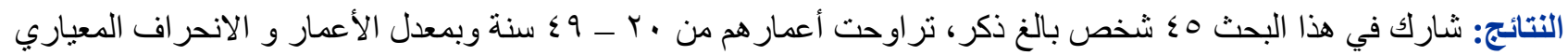

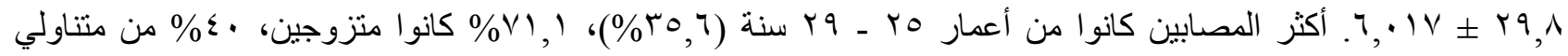





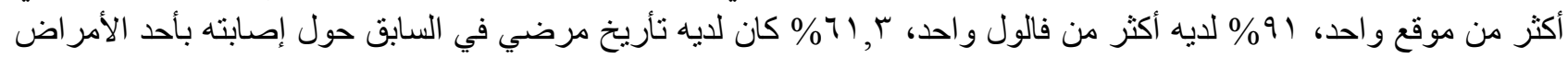




$$
\begin{aligned}
& \text { الجنسية الانتقالية، 70,\% 10 كانوا مصابين بمرض آخر من الأمر اض الجنسية الانتقالية وكل المصابين أصيبوا عن طريق التماس }
\end{aligned}
$$



$$
\begin{aligned}
& \text { و التقالبد الاجتماعية والدينية التي تحد من حرية وتجاوز العلاقات الجنسية. }
\end{aligned}
$$

A no-genital warts (condylomata acuminata) consist of epidermal and dermal papules or nodules on the perineum, genitalia, crural folds, and anus. They vary in size and can form large, cauliflower like masses, especially in the moist environment of the perineum. Discrete sessile warts $(1-3 \mathrm{~mm})$ may occur on the penile shaft. Lesions that resemble common warts also occur in this region but are unusual ${ }^{(1-3)}$. The diagnosis of viral wart is usually made by the clinical appearance but can also be confirmed by histological examinations ${ }^{(4)}$.

HPV-6 (human papilloma virus) and HPV-11 are the main causes of ano-genital warts ${ }^{(5)}$. Genital warts have a high infectivity and it's assumed that any sexual contact with a patient has genital warts is also likely to be infected. The thinner mucosal surface is presumably more susceptible to inoculation of virus than is thicker keratinized skin; in addition, lesions were noted to be commonest in sites subject to greatest coital friction in both sexes $^{(6)}$. There are also epidemiological parallels between ano-genital warts and other sexually transmitted diseases ${ }^{(6)}$. Patients with genital warts frequently have other genital infections. These are mainly minor conditions such as candidiasis, trichomoniasis and non-specific genital infection with occasional major venereal infections (syphilis or gonorrhoea) ${ }^{(7,8)}$, although in some series based in venereology departments, the incidence of these associated infections has been as high as 10\%$20 \%{ }^{(6,9)}$. Ano-genital warts are common, with an estimated 1.3 million new cases per year in the USA. They are often asymptomatic, but may cause discomfort, discharge or bleeding. The typical anogenital wart is soft, pink, elongated and sometimes filiform or pedunculated. The lesions are usually multiple especially on moist surfaces ${ }^{(6)}$. The commonest sites, the area of frenulum, corona and glans in men, correspond to the likely sites of greatest coital friction ${ }^{(6)}$. Most other lesions are flat, though more conspicuous than plane warts elsewhere, and some of these, generally on non- mucosal surfaces such as the penile shaft, pubic skin, perianal skin and groins ${ }^{(6,10)}$.

The prevalence of HPV worldwide is approximately $10 \%^{(11)}$, it is estimated to be the most commonly occurring sexually transmitted disease (STI) in the United States (12). Annually, one million cases are reported in USA, with a prevalence rate of approximately $30 \%{ }^{(13)}$. Over the past 50 years, there has been a steady increase in the incidence of ano-genital warts ${ }^{(14)}$. A study in the UK in 1994 estimated the incidence in young adults aged 16-24 to be 500 per 100 000, with an overall population incidence of 300 per $100000^{(15)}$. In England in 2008, there were 80531 new (157/100 000 population) and 68259 recurrent (133/100 000 population) episodes, giving a total of 148790 episodes of genital warts (289/100 000 population) ${ }^{(16)}$. A study in Rochester, Minnesota, in 1980s recorded an annual incidence of 106.5 per 100000 , or about $0.1 \%{ }^{(17)}$.

Up to the researchers' knowledge, no study concerning the genital warts in Erbil city was published, which motivated them to highlight on such problem to find out the epidemiological and clinical pattern of this disease in the city.

\section{PATIENTS AND METHODS}

This is a cross-sectional study; a convenient sampling method was used for data collection from male patients that have clinical features of genital warts attending two private dermatology clinics in Erbil city from $15^{\text {th }}$ June 2009 through $15^{\text {th }}$ June 2011. A special questionnaire that was including socio-demographic as well as clinical and laboratory findings was designed. The first and second author have interviewed the patients individually by themselves and filled the questionnaire accordingly taking verbal consent from the patients. All the patients were advised that their partners to be examined by a gynecologist or female dermatologist to rule out their infection. Statistical package of social 
sciences (SPSS) program version 18 was used for data entry and data analysis.

\section{RESULTS}

Tables 1-9 show the various parameters of the study sample;

Table 1 shows the age distribution of all studied patients.

Table 2 shows social statuses and habits of all patients.

Table 3 highlights the education level of the study population.

Table 4 shows the occupations of included patients.

Table 1. Age distribution of study sample.

\begin{tabular}{|c|c|c|}
\hline Age group & Frequency (\%) & $\begin{array}{c}\text { Cumulative } \\
\text { Percent }\end{array}$ \\
\hline $20-24$ & $9(20.0)$ & 20.0 \\
\hline $25-29$ & $16(35.6)$ & 55.6 \\
\hline $30-34$ & $11(24.4)$ & 80.0 \\
\hline $35-39$ & $5(11.1)$ & 91.1 \\
\hline $40-44$ & $3(6.7)$ & 97.8 \\
\hline $45-49$ & $1(2.2)$ & 100.0 \\
\hline Total & 45 & \\
\hline
\end{tabular}

Table 2. Social status and habits of the study sample.

\begin{tabular}{|c|c|c|c|}
\hline \multicolumn{2}{|c|}{ Variables } & $\begin{array}{c}\text { Frequency } \\
(\%)\end{array}$ & $\begin{array}{c}\text { Cumulative } \\
\text { Percent }\end{array}$ \\
\hline \multirow{2}{*}{$\begin{array}{c}\text { Marital } \\
\text { status }\end{array}$} & Married & $32(71.1)$ & 71.1 \\
\cline { 2 - 4 } & Single & $13(28.9)$ & 100 \\
\hline \multirow{2}{*}{$\begin{array}{c}\text { Alcohol } \\
\text { drinking }\end{array}$} & No & $27(60)$ & 60 \\
\cline { 2 - 4 } & Yes & $18(40)$ & 100 \\
\hline $\begin{array}{c}\text { Type of } \\
\text { partner }\end{array}$ & Marital & $13(28.9)$ & 28.9 \\
\cline { 2 - 4 } & Extramarital & $32(71.1)$ & 100 \\
\hline \multirow{2}{*}{$\begin{array}{c}\text { Use of } \\
\text { condom }\end{array}$} & No & $40(88.9)$ & 88.9 \\
\cline { 2 - 4 } & Yes & $5(11.1)$ & 100 \\
\hline $\begin{array}{c}\text { No. of } \\
\text { sexual } \\
\text { partner }\end{array}$ & One & $15(33.3)$ & 33.3 \\
\cline { 2 - 4 } & $\geq$ One & $30(66.7)$ & 100 \\
\hline
\end{tabular}

Table 3. Educational level of study sample.

\begin{tabular}{|l|c|c|}
\hline Educational status & $\begin{array}{c}\text { Frequency } \\
(\%)\end{array}$ & $\begin{array}{c}\text { Cumulative } \\
\text { Percent }\end{array}$ \\
\hline Illiterate & $5(11.1)$ & 11.1 \\
\hline Primary school & $19(42.2)$ & 53.3 \\
\hline Secondary school & $10(22.2)$ & 75.6 \\
\hline $\begin{array}{l}\text { Preparatory (Two } \\
\text { years institutions) }\end{array}$ & $5(11.1)$ & 86.7 \\
\hline College & $5(11.1)$ & 97.8 \\
\hline Higher education & $1(2.2)$ & 100.0 \\
\hline Total & 45 & \\
\hline
\end{tabular}

Table 5 shows that $40(88.9 \%)$ of the cases were not using condoms during their sexual contact, and those who were using condoms were $5(11.1 \%)$; two of them were of primary education, and the others of secondary, preparatory and college level education.

Table 6 shows that the highest rate $(60 \%)$ of the skin lesions was papular in shape, while the lowest rate $(2.2 \%)$ of the lesions was flat in shape.

Table 7 shows that $(46.7 \%)$ of the lesions affecting one site, and $(53.3 \%)$ affecting more than one site of external genital areas.

Table 8 shows that $(91 \%)$ of the cases have multiple warts, while $(9 \%)$ have single wart.

Table 9 shows that $(15.6 \%)$ of the cases were associated with other sexually transmitted infections (STI), including: gonorrhea, trichomonas vaginalis, hepatitis $B$, and scabies $(6.6 \%, 4.4 \%$, $2.2 \%, 2.2 \%$ ) respectively.

Table 4. Frequency distribution of the disease by occupation.

\begin{tabular}{|l|c|}
\hline \multicolumn{1}{|c|}{ Occupation categories } & Frequency (\%) \\
\hline Drivers & $5(11.1)$ \\
\hline Self employee professional & $7(15.6)$ \\
\hline $\begin{array}{l}\text { Self employee workers non- } \\
\text { professional }\end{array}$ & $13(28.9)$ \\
\hline Unemployed & $20(44.4)$ \\
\hline Grand Total & 45 \\
\hline
\end{tabular}

Table 5. Educational level of study sample who use condom.

\begin{tabular}{|l|c|c|c|}
\hline \multirow{2}{*}{ Educational status } & \multicolumn{2}{|c|}{ Use of condom } & \multirow{2}{*}{ Total } \\
\cline { 2 - 3 } & $\begin{array}{c}\text { No } \\
\text { No. (\%) }\end{array}$ & $\begin{array}{c}\text { Yes } \\
\text { No. (\%) }\end{array}$ & \\
\hline Illiterate & $7(17.5)$ & $0(0)$ & $7(15.6)$ \\
\hline Primary school & $17(42.5)$ & $2(40)$ & $19(42.2)$ \\
\hline Secondary school & $8(20)$ & $1(20)$ & $9(20)$ \\
\hline $\begin{array}{l}\text { Preparatory (two } \\
\text { years institutions) }\end{array}$ & $4(10)$ & $1(20)$ & $5(11.1)$ \\
\hline College & $3(7.5)$ & $1(20)$ & $4(8.9)$ \\
\hline Higher education & $1(2.5)$ & $0(0)$ & $1(2.2)$ \\
\hline Total & $40(88.9)$ & $5(11.1)$ & 45 \\
\hline
\end{tabular}

Table 6. Morphology of the genital warts.

\begin{tabular}{|l|c|c|}
\hline \multicolumn{1}{|c|}{ Types } & $\begin{array}{c}\text { Frequency } \\
(\%)\end{array}$ & $\begin{array}{c}\text { Cumulative } \\
\text { Percent }\end{array}$ \\
\hline Flat & $1(2.2)$ & 2.2 \\
\hline Cauliflower-like & $5(11.1)$ & 13.3 \\
\hline Papule & $27(60.0)$ & 73.3 \\
\hline Mixed & $12(26.7)$ & 100.0 \\
\hline Total & 45 & \\
\hline
\end{tabular}


Table 7. Anatomical distribution of genital warts.

\begin{tabular}{|c|c|c|}
\hline \multirow{4}{*}{ Single } & Types & Frequency (\%) \\
\cline { 2 - 3 } & Penis shaft & $17(37.8)$ \\
\cline { 2 - 3 } & Scrotum & $1(2.2)$ \\
\cline { 2 - 3 } & Anus & $2(4.4)$ \\
\hline \multirow{5}{*}{ Supra pubic region } & $1(2.2)$ \\
\cline { 2 - 3 } & Total & $21(46.7)$ \\
\cline { 2 - 3 } & $1 \& 2$ & $1(2.2)$ \\
\cline { 2 - 3 } & $1 \& 3$ & $10(22.2)$ \\
\cline { 2 - 3 } & $1 \& 4$ & $1(2.2)$ \\
\cline { 2 - 3 } & $1 \& 5$ & $9(20.0)$ \\
\cline { 2 - 3 } & $5 \& 3$ & $1(2.2)$ \\
\cline { 2 - 3 } & $1,2 \& 5$ & $1(2.2)$ \\
\cline { 2 - 3 } & $1,2,3 \& 5$ & $24(53.3)$ \\
\cline { 2 - 3 } & Total & $1(2.2)$ \\
\hline
\end{tabular}

1: Penis shaft, 2: Glance penis, 3: Scrotum, 4: Anus and 5: Supra-pubic.

Table 8. Modes of presentation of cases.

\begin{tabular}{|c|c|c|c|}
\hline \multicolumn{2}{|c|}{ Variables } & \multirow{2}{*}{$\begin{array}{c}\text { Frequency } \\
\text { (\%) }\end{array}$} & \multirow{2}{*}{$\begin{array}{c}\begin{array}{c}\text { Cumulative } \\
\text { Percent }\end{array} \\
8.9\end{array}$} \\
\hline Number of & Single & & \\
\hline warts & Multiple & $41(91.1)$ & 100 \\
\hline \multirow{2}{*}{$\begin{array}{l}\text { Genital } \\
\text { growth or } \\
\text { tumor }\end{array}$} & No & $1(2.2)$ & 2.2 \\
\hline & Yes & $44(97.8)$ & 100 \\
\hline \multirow{2}{*}{ Pruritis } & No & $41(91.1)$ & 68.9 \\
\hline & Yes & $4(8.9)$ & 100 \\
\hline \multirow{2}{*}{ Pain } & No & $42(93.3)$ & 86.7 \\
\hline & Yes & $3(6.7)$ & 100 \\
\hline \multirow{2}{*}{$\begin{array}{l}\text { Urethral } \\
\text { discharge }\end{array}$} & No & $42(93.3)$ & 93.3 \\
\hline & Yes & $3(6.7)$ & 100 \\
\hline \multirow{2}{*}{$\begin{array}{l}\text { Lower } \\
\text { abdominal } \\
\text { pain }\end{array}$} & No & $42(93.3)$ & 93.3 \\
\hline & Yes & $3(6.7)$ & 100 \\
\hline \multirow{2}{*}{$\begin{array}{l}\text { Painful } \\
\text { sexual } \\
\text { intercourse }\end{array}$} & No & $40(88.9)$ & 88.9 \\
\hline & Yes & $5(11.1)$ & 100 \\
\hline \multirow{2}{*}{$\begin{array}{l}\text { Past history } \\
\text { of STIs }\end{array}$} & No & $40(88.9)$ & 88.9 \\
\hline & Yes & 5 (11.1) & 100 \\
\hline \multirow{2}{*}{$\begin{array}{l}\text { Presence of } \\
\text { warts in } \\
\text { other parts of } \\
\text { the body }\end{array}$} & No & 45 (100) & 100 \\
\hline & Yes & $0(0.0)$ & 100 \\
\hline
\end{tabular}

Table 9. Frequency of association of the genital warts with other sexually transmitted disease.

\begin{tabular}{|l|c|}
\hline \multicolumn{1}{|c|}{ Name of diseases } & Frequency (\%) \\
\hline Gonorrhea & $3(6.6)$ \\
\hline Trichomonas vaginalis & $2(4.4)$ \\
\hline Hepatitis B & $1(2.2)$ \\
\hline Scabies & $1(2.2)$ \\
\hline Total & $7(15.6)$ \\
\hline
\end{tabular}

\section{DISCUSSION}

Up to the researchers' knowledge this study is the first of its kind conducted in Erbil city, on one of the most common sexually transmitted infection, genital warts, which is caused by HPV.

Recording of 45 cases of genital wart during the study period of more than 2 years in private clinics of two dermatoveneriologists implies that the disease rate is much lower than that found in other countries ${ }^{(13,14,18)}$. A study conducted in Baghdad, (19) showed that only $0.46 \%$ of dermatological cases attending two major hospitals at dermatology consultation units have genital warts. Although the study sample is not representing the whole Erbil governorate, but there is still another indicator supporting observation of the low rate of the disease which is the annual official statistics of recorded cases of male genital warts in Erbil governorate for the year 2005 which was 10 cases in a community of $1,345,000$ population ${ }^{(20)}$. This low rate of the disease may be attributed to (1) the cultural and religious basis of this community which limits the sexual habits of individuals, in form of sexual contact between married persons only, which is one of the distinct ways in primary prevention of STIs ${ }^{(21)}$; The source of infection seems to be from prostitute women. (2) Another factor that may explain this low rate of the disease is male circumcision among the studied population of which majority of them are Muslims, as uncircumcised men are at a greater risk for infection and persistence for genital warts ${ }^{(22)}$.

The current study revealed that the commonest age group affected by this disease was 25-29 years old, which is in concordance with that reported in Baghdad ${ }^{(19)}$, USA ${ }^{(18)}$, and Australia ${ }^{(23)}$ and this may be due to the fact that, sexual activity is at its highest level at this period of life ${ }^{(21)}$.

The disease frequency in current study is declining after the age of 35 years, reaching to zero after the age of 50 years, which is consistent 
with that recorded in Baghdad ${ }^{(19)}$, unlike with that recorded in $\mathrm{USA}^{(18)}$ in which there is a considerable number of cases above this age reaching up to 65 years or more. This can be explained on the basis that sexual activity is age limited in our community and also the cultural background and belief may have deterrent effect on so many activities including sexual actions especially in such ages; the person is more likely to avoid unfaithful sexual contacts, and also the older person will be a symbol to his family and society.

Although, $(71 \%)$ of the study sample were married it didn't prevent the transmission of the disease. The majority of cases $(70 \%)$ had history of extramarital sexual contacts; others may have denied it because of the sensitivity of the question. Extramarital sexual contact had shown to be a risk factor for contracting the disease, as it is the risk factor for other STIs, and the educational program role remains crucial for informing the community about that.

When an STI appears; usually there is a third $X$ person who is regarded as a source of the infection. The number of lifetime sexual partners is the single most established risk factor for genital HPV infection ${ }^{(24,25)}$. This may explain the high number $(66 \%)$ of those who had more than one sexual partner in this study, as was found by others $^{(22,26-29)}$.

Alcoholism was present among a considerable number of study sample $(40 \%)$, as seen in one study $^{(23)}$. This may be more than expected in Islamic population, this factor i.e. alcoholism, have an effect in encouraging the person for sexual promiscuity.

The occupation of study sample showed that non professional employees and drivers have a high frequency of infection, which is consistent with studies in other areas ${ }^{(23)}$, as the persons engaged in occupations involving frequent travel are among the high risk group for contraction of sexually transmitted diseases ${ }^{(21)}$.

Being more than half of the patients with low educational level reflects the role of educational level either in avoiding unfaithful sexual contact, or in increase the awareness of the person about the STIs and the ways of prevention.

The current study revealed that the majority of cases $(88.9 \%)$ are not using condoms during sexual contacts, it includes even those with high educational level which reflects either their poor knowledge about the importance of condoms in preventing STIs, or their trust to their $X$ sexual partner that she is free from any STI or she is faithful to him, since more than two third of study sample had history of relation with more than one sexual partner, and another reason may be the unavailability of condoms. Although condoms do not completely prevent HPV transmission, but consistent condom use has been demonstrated to reduce the risk of acquiring HPV by $70 \%{ }^{(30)}$. In addition, condoms have been shown to reduce the risk of HPV-associated disease, including genital warts, cervical intraepithelial neoplasia and invasive cervical cancer ${ }^{(31)}$ as well as promote the regression of HPV-associated cervical disease and flat penile lesions and the clearance of HPV infection ${ }^{(30,31)}$.

In the current study, the shaft of penis was the commonest involved site, while in most other studies, the commonest site is glans penis, frenulum and preputial sites ${ }^{(6,10)}$. This may be explained on the basis of the effect of circumcision in Islamic cultures which reduces the wetness and moisture that develop on glans penis and preputial region which are regarded as enhancers for the growth of the wart ${ }^{(21)}$. All the cases were free from viral warts in the other sites of the body (hands, face, feet...etc), which strengthens the idea that all the cases were contracted from sexual contact. Although $2(4.4 \%)$ of the cases had warts at peri anal region, but they didn't declare any history of homosexuality.

Patients with genital warts are usually seeking medical care very late, a finding that is similar to other study in USA ${ }^{(7)}$, it might be explained by the fact that discomforts, like pain, irritation or itching in genital area (symptoms that make the patients seeking medical care) are generally mild and are not taken seriously by the patient to seek early for medical care.

The low rate of past history of STIs $(11.1 \%)$ may be due to low level of knowledge of the patient about recognition of STIs, or the STIs are not so common in this population.

Association of $15.6 \%$ of the cases with other STIs is comparable with those recorded in other studies ${ }^{(6-9)}$, this raises the importance of screening of any case of genital warts for other STIs, and 
fortunately no case of HIV was diagnosed in this study, and the finding of only one case of hepatitis B $(2.2 \%)$ of the study population doesn't necessary indicate its contraction by sexual contact, as a study in Erbil showed $1 \%$ of the population is Hbsag is +ve ${ }^{(32)}$.

It is important to mention that the researchers found difficulty in comparing the results of this study with others in local areas and regional countries due to the lack of published studies, which also reflects the difficulty of touching such problems, for poor resources for data collection, so it may be one of the limitations of the study, but at the same time it reflects its strength to be one of the very few studies conducted in this field locally and among neighboring countries.

\section{CONCLUSION}

The study concluded that the genital warts are low or infrequent in Erbil city, when compared to other areas in the world. This low rate may be attributed to the difficulty to have multiple sex partners, and the conservative morale standards and attitude of this society towards sex free feature, with existence of traditional inhibition imposed by the religion and the society on the sexual behavior. The results of this study can be considered as a database for further studies in the future.

\section{REFERENCES}

1. Zachow KR, Ostrow RS, Bender M, et al. Detection of human papillomavirus DNA in ano-genital neoplasias. Nature 1982;300:771.

2. Ikenberg H.Human papillomavirus type-16 related DNA in genital Bowen's disease and in bowenoid papulosis. Int J Cancer 1983;32:563.

3. Bergeron C. Human papillomavirus type 16 in intraepithelial neoplasia (bowenoid papulosis) and coexistent invasive carcinoma of the vulva. Int $\mathrm{J}$ Gynecol Pathol 1987; 6(1):1-11.

4. Barrasso R. High prevalence of papillomavirusassociated penile intraepithelial neoplasia in sexual partners of women with cervical intraepithelial neoplasia. N Engl J Med 1987; 317:916.

5. Hall JC. Sauer's Manual of Skin Diseases. $9^{\text {th }}$ Edition. Lippincott: Williams \& Wilkins; 2006. p. 230, 475.

6. Oriel JD. Natural history of genital warts. $\mathrm{Br} \mathrm{J}$ Vener Dis 1971; 47: 1-13.

7. Chuang TY, Perry HO, Kurland LT. Condyloma acuminatum in Rochester, Minn., 1950-1978. II. Anaplasias and unfavorable outcomes. Arch Dermatol 1984; 120: 476-83.
8. Fairris GM, Statham BN, Waugh MA. The investigation of patients with genital warts. $\mathrm{Br} \mathrm{J}$ Dermatol 1984; 111: 736-8.

9. Kinghorn GR. Genital warts: incidence of associated genital infections. Br J Dermatol 1978; 99: 405-9.

10. Gross G, Ikenberg H, Gissmann L. Papillomavirus infection of the ano-genital region: correlation between histology, clinical picture and virus type. Proposal of a new nomenclature. J Invest Dermatol 1985; 85: 147-52.

11. De Sanjose S, Diaz M, Castellsague X. Worldwide prevalence and genotype distribution of cervical human papillomavirus DNA in women with normal cytology: a meta-analysis. Lancet Infect Dis 2007; 7:453.

12. Cates W J. Estimates of the incidence and prevalence of sexually transmitted diseases in the United States. American Social Health Association Panel. Sex Transm Dis 1999; 26:S2-7.

13. Partridge JM, Koutsky LA. Genital human papillomavirus infection in men. Lancet Infect Dis 2006; 6:21-31.

14. Kjaer SK, Lynge E. Incidence, prevalence and time trends of genital HPV infection determined by clinical examination and cytology. In: Muóz E, Bosch FX, Jensen OM, eds. Human Papillomavirus and Cervical Cancer. Lyon: IARC Scientific Publications; 1989.p. 113-24.

15. Simms I, Fairley CK. Epidemiology of genital warts in England and Wales: 1971 to 1994. Genitourin Med 1997; 73: 365-7.

16. Desai S, Wetten S, Woodhall SC, et al. Genital warts and cost of care in England. Sex Transm Infect 2011; 87(6):464-8.

17. Chuang TY, Perry HO, Kurland LT. Condyloma acuminatum in Rochester, Minn., 1950-1978. 1. Epidemiology and clinical features. Arch Dermatol 1984; 120: 469-75.

18. Insinga RP, Erik JD, Evan RM. The Health and Economic Burden of Genital Warts in a Set of Private Health Plans in the United States. Clin Infect Dis 2003; 36:1397-403.

19. Mohsin MK. Clinico-epidemiological study on viral warts in two hospitals in Baghdad. Fellowship of Iraqi medical specialists dissertation in community medicine. 2002. p.39.

20. Annual official statistics of Erbil Directorate of Health. Sexually Transmitted Diseases \& Emigration Unit Activities Report in Erbil during 2005.

21. Sehgal VN. Sexually transmitted diseases (Venerial diseases). $5^{\text {th }}$ edition. New Delhi: Jaypee brothers medical publishers LTD; 2010; 5-7,133-5.

22. Svare El, Kjaer SK, Worm AM, et al. Risk factors for genital HPV DNA in men resemble those found in women: a study of male attendees at a Danish STD clinic. Sex Transm Infect 2002;78(3):215-2I8. 
23. Wen LM, Estcourt CS, Simpson JM. Risk factors for the acquisition of genital warts: are condoms protective? Sex Transm Infect 1999; 75: 312-6.

24. Burk RD, Ho GY, Beardsley L, Lempa M, Peters M, Bierman R. Sexual behavior and partner characteristics are the predominant risk factors for genital human papillomavirus infection in young women. J Infect Dis 1996; 174(4):679-89.

25. Hippelainen $M$, Syrjanen $S$, Koskela $H$, et al. Prevalence and risk factors of genital human papillomavirus (HPV) infections in healthy males: a study on Finnish conscripts. Sex Transm Dis. 1993; 20(6):321-8.

26. Wang SS, Schiffman M, Shields TS, et al. Seroprevalence of human papillomavirus-16, -18, 31 , and -45 in a population-based cohort of 10000 women in Costa Rica. Br J Cancer 2003; 89(7): 1248-54.

27. Tarkowski TA, Koumans EH, Sawyer $M$, et al. Epidemiology of human papillomavirus infection and abnormal cytologic test results in an urban adolescent population. J Infect Dis 2004;189(1):4650 .
28. Wheeler CM, Parmenter CA, Hunt WC, et al. Determinants of genital human papillomavirus infection among cytologically normal women attending the University of New Mexico student health center. Sex Transm Dis 1993;20(5):286-9.

29. Franceschi $S$, Castellsague $X$, Dal Maso $L$, et al. Prevalence and determinants of human papillomavirus genital infection in men. $\mathrm{Br} \mathrm{J}$ Cancer 2002; 86(5):705-11.

30. Manhart LE, Koutsky LA. Do condoms prevent genital HPV infection, external genital warts, or cervical neoplasia? A meta-analysis. Sex Transm Dis. 2002;29:725-735.

31. Bleeker MG, Hogewoning GJ, Voorhorst FJ, et al. Condom use promotes regression of human papillomavirus-associated penile lesions in male sexual partners of women with cervical intraepithelial neoplasia. Int J Cancer 2003; 107: 804-810.

32. Othman SM. Epidemiology and risk factors of hepatitis $B$ infection in Kurdistan region. Ph.D. thesis. Community medicine department, college of medicine, Hawler medical university. 2010. p. 58. 